\title{
Exploring the Relationship between Corporate Social Responsibility, Employee Engagement, and Organizational Performance: The Case of Jordanian Mobile Telecommunication Companies
}

\author{
Bader Yousef Obeidat \\ Department of Business Management, The School of Business, The University of Jordan, Amman, Jordan \\ Email: b.obeidat@ju.edu.jo
}

How to cite this paper: Obeidat, B.Y. (2016) Exploring the Relationship between Corporate Social Responsibility, Employee Engagement, and Organizational Performance: The Case of Jordanian Mobile Telecommunication Companies. Int. J. Communications, Network and System Sciences, 9, 361-386.

http://dx.doi.org/10.4236/ijcns.2016.99032

Received: July 25, 2016

Accepted: September 12, 2016

Published: September 16, 2016

Copyright $\odot 2016$ by authors and Scientific Research Publishing Inc. This work is licensed under the Creative Commons Attribution International License (CC BY 4.0).

http://creativecommons.org/licenses/by/4.0/

\begin{abstract}
The aim of this research is to explore the relationship between corporate social responsibility, employee engagement, and organizational performance in Jordanian mobile telecommunication companies. A total of 350 questionnaires containing 37 items were used to collect information from the respondents. Multiple and simple regression analyses were conducted to test the research hypotheses. Results of the current study revealed that corporate social responsibility (both internal and external) and employee engagement (vigor, absorption, and dedication) have a significant positive relationship with organizational performance. Also, the results revealed that there is a significant positive relationship between corporate social responsibility (internal CSR and external CSR) and employee engagement. The Baron and Kenny mediation model and Sobel test were used to test whether employee engagement mediated the relationship between corporate social responsibility and organizational performance. The results showed that employee engagement fully mediated the relationship in a significant way. The results of the current study have many managerial implications for mobile telecommunication companies. In order to enhance organizational performance, decision makers must work on creating and maintaining an efficient corporate social responsibility agenda, which would increase employees' engagement in their work which will lead to improved performance outcomes.
\end{abstract}

\section{Keywords}

CSR, Employee Engagement, Organizational Performance, Mobile

Telecommunication, Jordan 


\section{Introduction}

Businesses are trying to flourish and adapt to the various challenges they encounter in today's competitive environment by improving their organizational performance [1] and [2]. In order to achieve better results and higher profit margins organizations are adopting various emerging business tools and management philosophies [3]. Some of these include corporate social responsibility and the engagement of employees. According to [4], companies are facing great pressure from stakeholders to become more socially and environmentally responsible and are also pressured to focus on developing a better understanding of how engaged employees affect business outcomes such as productivity and profitability. Over the years corporate social responsibility has become an important issue for corporations worldwide [5]. The interest in corporate social responsibility first emerged due to the public's increasing concern for the natural environment, for the respect of human rights, for the ethical aspects of business, and for other social concerns [6]. Business organizations, customers, investors, and other stakeholders have shown interest in corporate social responsibility as it is argued to socially desirable activities positively influence a firm's financial performance [7]. Furthermore, [8] stated that the interest in corporate social responsibility also stems from the fact that corporate social responsibility builds strong employee bonds with corporations and achieves better employee and organizational performance.

Corporate social responsibility may lead to greater gain not only for society but also for organizations as it leads to higher employee engagement [9]. This is supported by [10] who stated that employees and job applicants are seeking out companies that demonstrate a commitment to corporate social responsibility as these firms provide the opportunity to engage employees, attract new talent, retain customers, and enhance the company brand. Moreover, according to [11], since organizations nowadays are focusing on the notion of the triple bottom line (i.e. planet, people, and profit), corporate social responsibility has proven that it's not only useful for attracting talented employees but also a great way to maintain the engagement of its current employees. Therefore, it has been noted that corporate social responsibility holds the key to the success of organizations. This is because there is more to it than meets the eye since it can be used to address the needs of various stakeholders and at the same time address employee engagement challenges [12].

Organizations are trying to more sensitive with regard to their performance by focusing on employee performance. In this respect organizations are looking for people who will go beyond their defined career duties, develop cooperation, and help colleagues, employers, and customers [13]. Here engagement is considered a vital issue for companies who view their workforce as their greatest asset [10]. However leaders are aware of the many challenges that affect the engagement of their employees. But organizations that are able to overcome these challenges have enormous opportunities open to them especially in terms of business performance [14]. Indeed, disengaged employees may adversely affect productivity and revenues [12] [15]. As a result, it is important for organizations to create a culture and atmosphere that facilitate employee 
engagement and adopt different practices that enable them to maintain this engagement in order to ensure superior organizational performance [16].

After a thorough review of the literature it is clear that the relationship between corporate social responsibility, employee engagement, and organizational performance need further research and understanding particularly in developing countries like Jordan. Several scholars have pointed out that there is an imperative need for administering research in developed countries regarding the relationship between corporate social responsibility and organizational performance especially on employee's attitudes and behaviours (see [17]-[20]).

Regarding the relationship between corporate social responsibility and employee engagement, [21] stated that most research in the field of corporate social responsibility focused on external stakeholders and outcomes rather than focusing on how corporate social responsibility relates to internal stakeholders such as employees and the subsequent effect on of this relationship on performance. Regarding the relationship between employee engagement and organizational performance it is requested that this relationship be further investigated in terms of both qualitative and quantitative research methods [22]. The relationship between corporate social responsibility and organizational performance requires further examination as it has been reported that this relationship suffers from two limitations. First, extant research on this relationship focused only on western developed countries. Second, there is no consensus between scholars whether corporate social responsibility has a positive, negative, or neutral effect on organizational performance [23]. Therefore it is clear that there is a lack of literature regarding the relationship between corporate social responsibility, employee engagement, and organizational performance and as a result this researched is thus administered to answer the following question:

Is there a relationship between corporate social responsibility, employee engagement, and organizational performance in the Jordanian context?

\section{Corporate Social Responsibility (CSR)}

Since the 1970s much attention has been focused on the concepts of corporate social performance and corporate social responsibility, and it still continues to be a concept of interest today [24]. Academics and business managers have noticed how corporate social responsibility was an irrelevant and doubtful idea and how it has become a crucial topic on research agendas [25]. Organizations have come to terms that adopting a socially responsible view of its activities are of vital importance. This realization is due to the fact that organizations are faced with various social, economic, legal, ethical, and environmental challenges that affect their behaviour, and focusing solely on economic management to achieve objectives is no longer feasible [26]. Furthermore, organizations are pressured by a range of stakeholders such as communities, regulators, nongovernmental organizations, activists, socially responsible investors, etc. to become more socially responsible and behave as responsible corporate citizens [4]. According to [7], organizations engage in corporate social responsibility for a number of reasons which help to improve their overall financial portfolio. These reasons include following 
government regulations, improving public image, providing transparency for investors, and improving economic performance.

Corporate social responsibility can be traced on a continuum. At one end of the continuum it reflects the philanthropic activities that contribute to social and environmental requests received by the company or gaps identified by top management. These activities have no effect on a company's core activities, technologies, or business model. At the other extreme it reflects a set of practices created in response to demands placed on society and the activities of the organization by various dynamic forces [27]. [28] refers to corporate social responsibility as voluntary or disinterested activities that lead to the attainment of some social good. Business for Social Responsibility define corporate social responsibility as "a set of policies, practices, and programs that are integrated throughout business operations and decision making process, and intended to ensure the company maximizes the positive impacts of it operations on society" ([29], p. 497). Corporate social responsibility can be defined as an ongoing commitment made by organizations to act in an ethical manner and enhance economic development while improving the quality of life of employees and their families, local community, and society as a whole [7] [30] [31]. Corporate social responsibility can also be seen as "the firm's considerations of, and responses to, issues beyond the narrow economics, technical, and legal requirements of the firm to accomplish social [and environmental] benefits along with the traditional economic gains which the firm seeks" ([32], p. 234). The idea behind corporate social responsibility is that organizations should try to achieve a balance between profits achieved and expenses made by maximizing the positive influence and minimising the negative effects in achieving the contribution for society [33]. Socially responsible firms are economically competitive organizations that try to fulfil required tasks in order to assure their survival and existence. This requires the fulfilment of certain conditions which include offering products and services that respond to the user's needs, performing above minimum requirements, acting ethically, providing safe and healthy working conditions, respecting the environment, and integrating the company into the community [26]. Socially responsible firms should also compete for stakeholder goodwill and try to differentiate themselves from competitors by combining business opportunities and social welfare [6]. However, corporations will not act responsibly as long as corporate responsibility issues are not integrated in their decision making and governance structures. This importance is thus highlighted as it has been reported that $80 \%$ of the global fortune 250 firms now release corporate social responsibility information and $75 \%$ have a formal corporate social responsibility strategy in place [34].

Organization can engage in many types of corporate social responsible behaviours such as being employee friendly, investor friendly, environmentally friendly, mindful of ethics, respectful of communities, supporting the arts, universities and other causes [35]. [36] suggested that organizations can be socially responsible by acting responsibly towards the environment, treating employees fairly, and contributing to the arts and cultural programs in the community. Being able to engage in socially responsible activities benefits organizations in many ways, for example it strengthens relationships with dif- 
ferent stakeholders by minimizing conflicts with stakeholders and maximizing loyalty from all stakeholders [8]. It can also help in building and sustaining of corporate reputation, the reduction of organizational cost through the enhancement of positive social effects and elimination of negative ones, the alignment of corporate and social values which in turn may lead to the identification of new opportunities, and positive performance outcomes [37].

Several approaches have been used to measure corporate social responsibility. [38] proposed a distinction between economic, legal, ethical, and discretionary CSR. [39] suggested viewing CSR from the various stakeholders' perspective. Other scholars suggested using CSR practices and grouping them into internal and external social roles (see [18] [40] [41]) which will be the basis of measurement for this study.

\subsection{Internal CSR}

Internal corporate social responsibility is related to all the internal operations of the company [42]. According to [43], internal CSR focuses on what can be done inside in the organization to improve the well-being of employees, their lives, and productivity, which in turn affects the organization's profitability and bottom line. Internal CSR practices refer to "CSR practices which are directly related with the physical and psychological working environment of employees" ([32], p. 234). This focus on employees is due to the fact that they are considered very important internal stakeholders to the organization [44]. According to [45], internal CSR practices can be classified into four groups named "value classes". These classes relate to development of employees' skills, social equity, health and safety at work, well-being and satisfaction of the worker, and quality of work.

\subsection{External CSR}

External corporate social responsibility refers to corporate socially responsible actions directed outside the boundaries of the organization [32]. [43] reported that external CSR promotes positive impacts of activities and operations on society and the natural environment. According to [46], external CSR activities relate to external stakeholders such as customers, business partners, and local communities. With regards to customers, socially responsible companies are required to provide products or services in an efficient, ethical, and environmentally friendly manner. Here customers not only look for quality products and services that comply with social responsible criteria but also for quality relationship with organizations that provide these products and services where they are able to provide proposals, complaints, and suggestions without any problem [45]. Regarding business partners, socially responsible companies are required to be good partners to their business partners and controlling labour standards in compliance with legal requirements and having in place complaints procedure for their suppliers and other business partners [45] [47]. Regarding local communities, socially responsible companies are required to take philanthropic initiatives such as sponsorship activities. In addition organizations are considered socially responsible if they 
make infrastructure investments [18], launch community development activities, encourage their employees to participate in community projects [48], and provide financial support to social and other non-commercial community projects [47]. These initiatives and activities add value for both the company and community.

\section{Employee Engagement (EE)}

In today's rapidly changing environment business leaders have come to realize that having high performing workforce is essential for the growth and survival of companies. Therefore, employee engagement has become a top priority for organizations as a highly engaged workforce can increase innovation, productivity, and bottom line performance while reducing costs of hiring and retaining talented employees [14].

Employee engagement does not have a single generally accepted definition that can be used as a common reference. Several scholars have provided many but somewhat similar definitions of the concept employee engagement. Engagement was first entered in the academic glossary by [49] who proposed that personal engagement occurs when people bring in or leave out their selves when performing their work roles. [50] defined employee engagement as a positive attitude held by employees toward the organization and its values. Here engaged employees are familiar with the business context and work with colleagues to benefit the organization. ([51], p. 9) referred to employee engagement as a "workplace approach designed to ensure the employees are committed to their organization's goals and values, motivated to contribute to organizational success, and are able at the same time to enhance their own sense of well-being". [52] defined engagement as the emotional and intellectual commitment of individuals or groups to an organization that affects business performance. ([53], p. 103) use work engagement to refer to employee engagement and state that it is "an individual employee's cognitive, emotional, and behavioural state directed toward desired organizational outcome". According to [54], employee engagement is a construct that captures the differences between individuals and the amount of energy and dedication they provide to their jobs.

Organizations should strive to have an engaged workforce since employers want employees who do their best to help their company succeed and employees want a good job that is challenging and meaningful. The only to achieve this win-win situation is through engagement [4] [55]. Furthermore, in order to develop and nurture engagement, a two-way relationship between employers and employees is required [56]. This is supported by [57] who stated that employee engagement is all about building great relationships with employees by embracing fine management philosophies, recognizing employees' talent and potential, and providing enriching professional experiences. According to them organizations who do this are bound to succeed. Engaged employees have many qualities such as wise self-starters, believe in supporting the organization, motivate co-workers, work with passion, have high energy level, enthusiastic, and often

involve themselves deeply in their jobs. Because of these qualities, engaged employees are expected to work better and smarter and thus lead to increased individual and or- 
ganizational performance and provide a foundation for sustainability [22] [57].

Many factors have been reported to facilitate or impede employee engagement. For example the [14] stated that recognition given to high performers, clear understanding of how jobs contribute to strategy, company-wide communication of goals, individual goals aligned with corporate goals, among others are considered important drivers of employee engagement. According to [57], there are several key drivers of employee engagement that help create a road map for achieving organizational excellence. Among these drivers are: Nature of the job, line of sight between employee and organizational performance, career growth opportunities, pride about the company, co-workers and team members, employee development, and relationship with one's manager. As a result organizations are required to understand and utilize various antecedents that help and facilitate employees to become engaged and maintain the engaged status [22] [58].

In order to determine whether employees in an organization are considered engaged or not three facets are taken into consideration: Vigor, dedication, and absorption. These three facets will be basis for measuring employee engagement in this study based on the study conducted by [32].

\subsection{Vigor}

Vigor is referred to as "high energy, resilience, a willingness to invest effort on the job, the ability not to be easily fatigued, and persistence when confronted with challenges" ([54], p. 47). Vigor is about the presence of four factors: 1) high energy levels; 2) mental resilience; 3) willingness to invest effort; and 4) the persistence in the face of challenges. All these factors are required in order for an individual to show vigor while performing a certain job [59].

\subsection{Dedication}

Dedication refers to "being strongly involve in one's work and experiencing a sense of significance, enthusiasm, inspiration, pride, and challenge" ([54], p. 70). According to [32], dedication is all about the mental and emotional state that reflects a sense of significance, enthusiasm, inspiration, and pride on experience. A person cannot be labelled as dedicated without the presence of such factors.

\subsection{Absorption}

Absorption refers to "a pleasant state of being immersed in one's works experiencing time passing by quickly and being unable to detach from the job” ([54], p. 47). A person who is absorbed in his or her job is characterized by being fully concentrated in his or her job, does not feel time passing by while performing the job, and has difficulty detaching or removing his or her self from work [59].

\section{Organizational Performance (OP)}

As organizations embark on an era characterized by globalization and digitization, organizational performance has become a major concern amidst existing and emerging 
challenges [60] [61]. Furthermore it has been noticed that the basis for determining organizational success or failure of both profit and non-profit organizations is organizational performance [62]. Therefore, businesses are striving to increase their performance [56] [63]. It is of vital importance for organizations to know and understand which factors influence an organization's performance in order to take appropriate steps to make them available [62]. According to [64], organizational performance is the result of several business factors such as work processes, team/group communication and interaction, corporate culture and image, policies, leadership, and climate that promotes innovation, creativity, and loyalty.

The concept of organizational performance has been around for many years and has seen many transformations over the years. In the 1950s organizational performance referred to the extent to which organizations fulfilled their objectives. In the 1960s and 1970s organizational performance was defined as the ability of an organization to exploit its environment for accessing and utilizing limited resources. In the 1980s and 1990s organizational performance was seen as the ability to accomplish goals (effectiveness) using minimum resources (efficiency) [65]. In the twenty first century many definitions of organizational performance have been reported. According to [66], organizational performance refers to the ability of organizations to meet the needs of stakeholders and its own needs for survival. [67] suggested that organizational performance is based on the premise of using human, physical, and capital resources in order to achieve a shared purpose. ([68], p. 43) defined organizational performance as "a measure of how well organizations are managed and the value of they deliver to customers and other stakeholders". All in all the essence of performance is value creation. So as long as the value created by the use of various assets owned by the organization is greater than or equal the value expected by the use of these assets, the assets will continue to be made available to the organization thus ensuring the existence of the organization [67] [69].

Since organizational performance comprises the actual output or results of an organization compared to its expected outputs, measuring organizational performance is crucial as it allows organizations to assess how well work is done and thus be able to focus attention on areas that require improvement [70]. Many organizations have realized the importance of continuously evaluating performance and have adopted various approaches to evaluate performance [71] [72]. For many years organizations have performance evaluations solely on financial criteria which has been criticized for it many flaws [13]. These financial measures' biggest flaws are its inability to distinguish differences between firms and it gives misleading information about continuous improvement and innovation which is completely the opposite of what firm desire [73]. As a result it is clear that evaluating performance of organizations requires the consideration of several other organizational goals and not focusing only on financial goals. However, many organizations have neglected nonfinancial goals or measures of organizational performance as they difficult to manipulate and control due to their subjective and susceptive nature [64]. Nonfinancial goals need to be considered when measuring or- 
ganizational performance as many stakeholder groups are considered important in today's business environment other than a company's shareholders. Therefore, all stakeholders need to be taken into account when assessing organizational performance without preference of one group over another [70] and [74].In this study organizational performance will be measured using the dimensions of product/service quality, customer satisfaction, employee retention, employee attraction, management-employee relations, and employee relations as suggested by [75].

\section{Research Methodology}

\subsection{Research Model and Hypotheses}

The major elements of this research are established based on previous literature, either theoretically or empirically. Figure 1 represents a model for the study that shows the independent variables within the construct of corporate social responsibility, the mediating variable (employee engagement), and the dependent variable (organizational performance), and the proposed relationship between them.

In order to test the relationship among corporate social responsibility, employee engagement, and organizational performance, the following null hypotheses were developed.

$\mathrm{H}_{01}$ : There is no statistically significant relationship (at the level $\alpha=0.05$ ) between corporate social responsibility and organizational performance.

$\mathrm{H}_{01.1}$ : There is no statistically significant relationship (at the level $\alpha=0.05$ ) between internal CSR and organizational performance.

$\mathrm{H}_{01.2}$ : There is no statistically significant relationship (at the level $\alpha=0.05$ ) between external CSR and organizational performance.

$\mathrm{H}_{02}$ : There is no statistically significant relationship (at the level $\alpha=0.05$ ) between corporate social responsibility and employee engagement.

$\mathrm{H}_{02.1}$ : There is no statistically significant relationship (at the level $\alpha=0.05$ ) between internal CSR and employee engagement.

$\mathrm{H}_{02.2}$ : There is no statistically significant relationship (at the level $\alpha=0.05$ ) between external CSR and employee engagement.

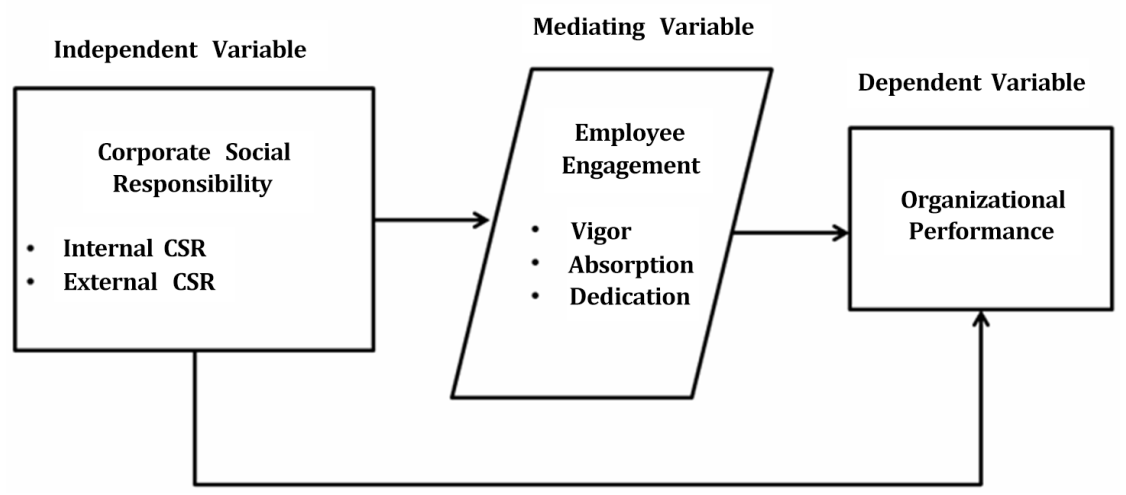

Figure 1. Research model. 
$\mathrm{H}_{03}$ : There is no statistically significant relationship (at the level $\alpha=0.05$ ) between employee engagement and organizational performance.

$\mathrm{H}_{03.1}$ : There is no statistically significant relationship (at the level $\alpha=0.05$ ) between vigor and organizational performance.

$\mathrm{H}_{03.2}$ : There is no statistically significant relationship (at the level $\alpha=0.05$ ) between absorption and organizational performance.

$\mathrm{H}_{03.3}$ : There is no statistically significant relationship (at the level $\alpha=0.05$ ) between dedication and organizational performance.

$\mathrm{H}_{04}$ : Employee engagement does not mediate the relationship between corporate social responsibility and organizational performance.

\subsection{Research Design}

This research uses statistical package for social sciences version 19 in order to study the relationships proposed by the research model and to test the hypotheses. The basis for data collection and analysis is a field study in which respondents answered all items on a five point Likert-scales ranging from 1 (strongly disagree) to 5 (strongly agree). Furthermore, elements used to consider each of the constructs were primarily obtained from prior research. These elements provided a valued source for data gathering and measurement as their reliability and validity have been verified through previous research and peer reviews. Corporate social responsibility and its corresponding items (i.e. internal CSR and external CSR) were adapted from [18] [40] [41]. Employee engagement construct and its corresponding items (i.e. vigor, absorption, and dedication) were derived from [32]. Organizational performance construct was adapted from [75].

\subsection{Sample and Procedure}

The mobile telecommunication industry in Jordan is considered one of the most important industries and has seen huge growth in recent years. This industry is also one of the most competitive markets in the Middle East. According to Competition Intensity Index released by [76]-[78], Jordan's mobile market is the second most competitive in the region behind Saudi Arabia. All mobile telecommunication companies in Jordan represented the population used for this study. Based on the official statistical sources of the Jordanian Ministry of communication and information technology, there are three licensed mobile operators in Jordan: Zain, Uminah and Orange, with more than 10.7 million mobile subscriptions. According to a recent index produced by [76], Zain Jordan has the largest market share with $40 \%$ of the market, followed by Orange Jordan with $31 \%$. Then there's Umniah, the latest entrant that has $29 \%$ of the market share. The respondent of the study were all staff working in the three mobile telecommunication companies, and who are considered to be the population. Based on the three companies annual reports, the total number of employees working in mobile companies are about 1500 employees, and according to Morgan Table data, 300 employees were considered the appropriate sample size for this study [79]. 400 questionnaires were distributed to different employees, the total number of questionnaires returned was 350 and were considered usable for the data analysis stage. 


\section{Research Results}

\subsection{Validity and Reliability}

Validity and reliability are two important measures to determine the goodness of the study instrument; that is the quality and usefulness of the data collected. Validity relates to accuracy and whether the instrument measures what it is intended to measure, while reliability relates top recision; in other words it is used to check the consistency and stability of the questionnaire [80]. The researcher used scales and items that were previously developed and used by other researcher with similar interest to ensure content validity. Also, face validity was tested by creating a draft of the questionnaire that was then reviewed by four academic lecturers-who have a sufficient knowledge and experience regarding this topic-to ensure that each item is measuring what is intended to be measured, and to avoid any ambiguity and complexity in the phrasing of the questions. The reliability of the instrument was measured by the Cronbach's alpha coefficient. Some scholars [80] suggested that the values of all indicators or dimensional scales should be above the recommended value of 0.60 . Table 1 represents the results of Cranach's alpha for the independent, mediating, and dependent variables. Cronbach's alpha coefficients of all the tested variables were above 0.60 indicating that the study instrument is reliable.

\subsection{Hypotheses Testing Results}

The main purpose of conducting this study is to examine the relationship between corporate social responsibility, employee engagement, and organizational performance in Jordanian mobile telecommunication companies. Consequently, in order to test the hypotheses developed for this study, simple and multiple regression techniques were used. The level of significance was chosen to be 0.05 (and hence $95 \%$ level of confidence) as it is the level traditionally chosen for business research. Finally, according to the regression analysis results, the null hypotheses were either accepted or rejected and a justification for the decision was given. The results of testing the main and sub hypotheses are demonstrated in the following Tables 2-4.

Table 1. Reliability statistics.

\begin{tabular}{ccc}
\hline Variable & Cronbach's Alpha & No. of Items \\
\hline Corporate Social Responsibility & 0.819 & 15 \\
Internal CSR & 0.867 & 5 \\
External CSR & 0.839 & 10 \\
Employee Engagement & 0.861 & 16 \\
Vigor & 0.853 & 6 \\
Absorption & 0.872 & 5 \\
Dedication & 0.867 & 5 \\
Organizational Performance & 0.606 & 6 \\
\hline
\end{tabular}


The correlation coefficient $\mathrm{R}=0.637$ indicates that there is a positive correlation between CSR and organizational performance as mentioned above. This proves that the independent variables and dependent variable change in the same direction. $\mathrm{R}$ square, coefficient of determination, provides information regarding the goodness of fit of the regression model [79]. In other words, it represents the percentage of variance in the dependent variable that is explained by the variation in the independent variable [79]. The value of $\mathrm{R}^{2}=0.406$ indicates the amount of variations in organizational performance that is accounted by the fitted model and has been explained by CSR. The adjusted $\mathrm{R}^{2}$ indicates the generalizability of the model. It allows generalizing the results taken from the respondents to the whole population. It is noticed that the value of the adjusted $R^{2}=0.403$ is close to the value of $R^{2}=0.406$. If the adjusted $R^{2}$ is excluded from $\mathrm{R}^{2}$ the value will be $(0.406-0.403=0.003)$. This amount of reduction means that if the whole population participates in the study and the model has been fitted then, there will be $0.3 \%$ reduction in the variance of the outcome.

The next step is the analysis of variance (ANOVA) that allows us to statistically test the main null hypothesis. The results of the ANOVA table show that the F-ratio = 118.583 which is significant at level $\mathrm{p}<0.05$ (sig. $<0.001$ ), this result indicates that there is less than $5 \%$ chance that an F-ratio of this value would occur by chance alone. Since the p-value is smaller than the level of significance (0.05), the null hypothesis is rejected at $\mathrm{p}<0.05$ significance level. Hence, there is a statically significant relationship between CSR and organizational performance.

Table 2. Multiple regression for the first main hypothesis.

\begin{tabular}{lcccccccc}
\hline & $\mathrm{R}$ & $\mathrm{R}^{2}$ & $\begin{array}{c}\text { Adjusted } \\
\mathrm{R}^{2}\end{array}$ & F-Value & Sig & $\begin{array}{c}\text { Standardized } \\
\text { Beta }\end{array}$ & t-Value & Sig \\
& 0.637 & 0.406 & 0.403 & 118.583 & $<0.001$ & & & \\
& & & & & & 0.466 & 11.146 & $<0.001$ \\
Internal CSR & & & & & & 0.371 & 8.864 & $<0.001$ \\
External CSR & & & & & & & \\
\hline
\end{tabular}

Table 3. Multiple regression for the second main hypothesis.

\begin{tabular}{lcccccccc}
\hline & $\mathrm{R}$ & $\mathrm{R}^{2}$ & $\begin{array}{c}\text { Adjusted } \\
\mathrm{R}^{2}\end{array}$ & F-Value & Sig & $\begin{array}{c}\text { Standardized } \\
\text { Beta }\end{array}$ & t-Value & Sig \\
\hline & 0.771 & 0.594 & 0.591 & 253.593 & $<0.001$ & & & \\
Internal CSR & & & & & & 0.641 & 18.531 & $<0.001$ \\
External CSR & & & & & & 0.343 & 9.921 & $<0.001$ \\
\hline
\end{tabular}

Table 4. Multiple regression for the third main hypothesis.

\begin{tabular}{ccccccccc}
\hline & $\mathrm{R}$ & $\mathrm{R}^{2}$ & $\begin{array}{c}\text { Adjusted } \\
\mathrm{R}^{2}\end{array}$ & F-Value & Sig & $\begin{array}{c}\text { Standardized } \\
\text { Beta }\end{array}$ & t-Value & Sig \\
\hline & 0.851 & 0.724 & 0.722 & 303.114 & $<0.001$ & & & \\
Vigor & & & & & & 0.616 & 17.734 & $<0.001$ \\
Absorption & & & & & & 0.115 & 3.365 & 0.001 \\
Dedication & & & & & & 0.378 & 13.083 & $<0.001$ \\
\hline
\end{tabular}


Results from the coefficients table, the $t$ and sig. (which is known as p-value) values, give a rough indication of the contribution of each predictor variable [81]. A large absolute $\mathrm{t}$-value and small $\mathrm{p}$-value suggests that the predictor variable does contribute to the criterion variable. The results show that all the dimensions of CSR are significant contributors to organizational performance ( $\mathrm{p}$-value $<0.05$ ). Furthermore, the standardized beta coefficient is a measure of the contribution of the predictor variable to the criterion variable [81]. A large value indicates that a unit change in this predictor variable has a large effect on the criterion variable. In this study internal CSR has the most contribution to organizational performance with a $\beta$ of 0.466 which indicates that it is a strong predictor of organizational performance. External CSR follows with $\beta$ values of 0.371 . Based on the results obtained from the multiple regression $\mathrm{H}_{01.1}$ and $\mathrm{H}_{01.2}$ were rejected.

The correlation coefficient $\mathrm{R}=0.771$ indicates that there is a positive correlation between CSR and employee engagement as mentioned above. This proves that the independent variables and dependent variable change in the same direction. $\mathrm{R}$ square, coefficient of determination, provides information regarding the goodness of fit of the regression model [79]. In other words, it represents the percentage of variance in the dependent variable that is explained by the variation in the independent variable. The value of $R^{2}=0.594$ indicates the amount of variations in employee engagement that is accounted by the fitted model and has been explained by CSR. The adjusted $\mathrm{R}^{2}$ indicates the generalizability of the model. It allows generalizing the results taken from the respondents to the whole population. It is noticed that the value of the adjusted $R^{2}=$ 0.591 is close to the value of $R^{2}=0.594$. If the adjusted $R^{2}$ is excluded from $R^{2}$ the value will be $(0.594-0.591=0.003)$. This amount of reduction means that if the whole population participates in the study and the model has been fitted then, there will be $0.3 \%$ reduction in the variance of the outcome.

The next step is the analysis of variance (ANOVA) that allows us to statistically test the main null hypothesis. The results of the ANOVA table show that the F-ratio = 253.593which is significant at level $\mathrm{p}<0.05$ (sig. $<0.001$ ), this result indicates that there is less than $5 \%$ chance that an F-ratio of this value would occur by chance alone. Since the p-value is smaller than the level of significance (0.05), the null hypothesis is rejected at $\mathrm{p}<0.05$ significance level. Hence, there is a statically significant relationship between CSR and employee engagement.

Results from the coefficients table, the $t$ and sig. (which is known as p-value) values, give a rough indication of the contribution of each predictor variable [81]. A large absolute $\mathrm{t}$-value and small $\mathrm{p}$-value suggests that the predictor variable does contribute to the criterion variable. The results show that all the dimensions of CSR are significant contributors to employee engagement ( $\mathrm{p}$-value $<0.05$ ). Furthermore, the standardized beta coefficient is a measure of the contribution of the predictor variable to the criterion variable [79]. A large value indicates that a unit change in this predictor variable has a large effect on the criterion variable. In this study internal CSR has the most contribution to employee engagement with a $\beta$ of 0.641 which indicates that it is a strong 
predictor of employee engagement. External CSR follows with $\beta$ values of 0.343 . Based on the results obtained from the multiple regression $\mathrm{H}_{02.1}$ and $\mathrm{H}_{02.2}$ were rejected.

The correlation coefficient $\mathrm{R}=0.851$ which indicates that the relationship between employee engagement and organizational performance is positive and that both variables change in the same direction. The coefficient of variation $\mathrm{R}^{2}$ shows that $72.4 \%$ of the variation in the dependent variable (organizational performance) is explained by the independent variable (employee engagement). The adjusted $\mathrm{R}^{2}$ indicates the generalizability of the model. It allows generalizing the results taken from the respondents to the whole population. It is noticed that the value of the adjusted $\mathrm{R}^{2}=0.722$ is close to the value of $R^{2}=0.724$. If the adjusted $R^{2}$ is excluded from $R^{2}$ the value will be $(0.724-$ $0.722=0.002)$. This amount of reduction means that if the whole population participates in the study and the model has been fitted then, there will be $0.2 \%$ less variance in the outcome. The analysis of variance (ANOVA) allows us to statistically test the main null hypothesis. The above Table 4 shows the results of the ANOVA test, where the F-ratio $=303.114$ and the $p$-value $=0.000$, this result indicates that there is less than $5 \%$ chance that an F-ratio of this value would occur solely by chance. Since the p-value $(<0.001)$ is smaller than the significance level $(0.05)$, the null hypothesis is rejected and the alternative hypothesis is accepted indicating that there is a relationship between employee engagement and organizational performance.

The results in the coefficients table revealed that all the dimensions of employee engagement (vigor, absorption, and dedication) were significant predictors of organizational performance given that their significant betas were $0.616,0.115$, and 0.332 , respectively. Therefore, $\mathrm{H}_{03.1}, \mathrm{H}_{03.2}$, and $\mathrm{H}_{03.3}$ were rejected. In order to test the fourth main hypothesis that questions whether employee engagement mediates the relationship between CSR and organizational performance, the [82] model of mediation test was used. Although this test is old it is still considered a valid test for mediation. To test this hypothesis a combination of simple and multiple regression analyses were conducted as proposed by [82]. The results of the regression tests can be seen in Table 5 . The [82] model of mediation focuses on the unstandardized regression coefficients, therefore, the coefficients mentioned in the below table represent the unstandardized betas.

To determine whether employee engagement mediates the relationship between CSR and organizational performance the following rule should be followed: If the independent variable is no longer significant when the expected mediator is controlled, the finding supports full mediation. If the independent variable is still significant (i.e., both the independent variable and the expected mediator both significantly predict the dependent variable), the finding supports partial mediation [82]. Based on this rule, full mediation exists since CSR became non-significant when employee engagement entered the model. Researchers such as [83] have suggested that the Baron and Kenny approach to finding mediation should be supplemented by a formal test to determine the amount of the indirect effect as the Baron and Kenny model only provides whether an indirect effect exists or not without any indication of an amount of this effect. In order 
Table 5. Regression analysis for mediation of emotional intelligence on job performance through conflict.

\begin{tabular}{ccccc}
\hline Variables & $\begin{array}{c}\text { Step 1 } \\
\text { Organizational } \\
\text { Performance }\end{array}$ & $\begin{array}{c}\text { Step 2 } \\
\text { Employee } \\
\text { Engagement }\end{array}$ & $\begin{array}{c}\text { Step 3 } \\
\text { Organizational } \\
\text { Performance }\end{array}$ & $\begin{array}{c}\text { Step 4 } \\
\text { Organizational } \\
\text { Performance }\end{array}$ \\
\hline (Constant) & $1.614^{* *}$ & $1.061^{* *}$ & $0.791^{* *}$ & $0.776^{* *}$ \\
CSR & $0.604^{* *}$ & $0.732^{* *}$ & & 0.026 \\
Employee Engagement & 0.635 & 0.769 & $0.812^{* *}$ & $0.790^{* *}$ \\
$\mathrm{R}$ & 0.403 & 0.591 & 0.811 & 0.811 \\
$\mathrm{R}^{2}$ & 0.401 & 0.590 & 0.657 & 0.657 \\
Adj. $\mathrm{R}^{2}$ & $234.572^{* *}$ & $503.186^{* *}$ & $666.861^{\star *}$ & $332.933^{* *}$ \\
F-Value & & & & 0.655 \\
\hline
\end{tabular}

${ }^{* *} \mathrm{p} \leq 0.05$.

to calculate the indirect effect a test developed by [84] was used. According to [84], the unstandardized regression coefficient obtained from regressing the mediator to predict the dependent variable (adjusting for the independent variable) $(\beta=0.790)$ should be multiplied by the unstandardized regression coefficient obtained from regressing the independent variable to predict the mediator $(\beta=0.732)$. Thus, the indirect effect of CSR on organizational performance through employee engagement $=0.790^{*} 0.732=$ 0.578. To ensure that the indirect effect is significant, it is recommended to run Sobel test [84].

The Sobel test requires the computation of the raw regression coefficient (unstandardized coefficients) and the standard error for this regression coefficient for the association between the independent variable and the mediator (path a), and the association between the mediator and the dependent variable (adjusting for the independent variable, path $b$ ). The unstandardized $\beta$ for path (a) $=0.732$ and the standard error $=0.033$, and for path (b) unstandardized $\beta=0.790$ and the standard error $=0.049$. The data are then used to calculate the Sobel test value, where it was found that the $t$-value $=13.042$ and the p-value $<0.001$. These results showed that the null hypothesis should be rejected and the alternative hypothesis should be accepted since the p-value for the Sobel test $(<0.001)$ falls below the established alpha level of 0.05 , indicating that the association between the independent variable (CSR) and the dependent variable (organizational performance) is reduced significantly by the inclusion of the mediator (employee engagement) in the model; in other words, there is evidence of mediation.

\section{Discussion and Conclusion}

The aim of this research was to examine the relationship between corporate social responsibility, employee engagement, and organizational performance in Jordanian mobile telecommunication companies.

$\mathrm{H}_{01}$ : There is no statistically significant relationship (at the level $\alpha=0.05$ ) between corporate social responsibility and organizational performance.

The results of this study revealed that there is a significant positive relationship be- 
tween CSR and organizational performance. This result supports the conclusions of [7] [23] [85]-[89]. The reason behind this positive association may be attributed to the fact that organizations have relationships with many groups including customers, employees, communities, etc other than shareholders alone, and all these stakeholders affect and are affected by the actions of the organization. By balancing and addressing the needs of different shareholders, organizations can become more efficient at responding and adapting to various stakeholder demands [90]. Furthermore, according to firm-ascontract analysis, high organizational performance results from both separate satisfaction of bilateral relationships and the simultaneous coordination and prioritization of multilateral stakeholder interests [88]. As a result, focusing on the interests of different stakeholders enhances the organizations competitive advantage and long term value creation [90].

However, not all studies undertaken to examine the relationship between CSR and organizational performance have been favourable. Some previous studies have produced mixed results showing non-significant, negative, or no relationships (For e.g. [91]-[93]). One possible explanation for this is that the relationship between CSR and $\mathrm{OP}$ is indirect suggesting that some variables exist that mediate or moderate the relationship. Another reason is that previous studies focused mainly on consumers' perception of CSR activities with less attention paid to employees' perceptions [94]. Furthermore, it has been suggested that measurement issues and model misspecification may be possible reasons for the lack of consensus among different CSR-OP studies [90].

$\mathrm{H}_{02}$ : There is no statistically significant relationship (at the level $\alpha=0.05$ ) between corporate social responsibility and employee engagement.

It has been found through this study that the presence of CSR in an organization leads to increased levels of employee engagement. This result is consistent with the findings of [20] [24] [32] [95]-[97] suggested that individuals have a need to classify themselves and others into social groups in an effort to derive part of their identity from that group. Within this context, belonging to a group and sharing common goals can help explain employees' perceptions, feelings, and behaviours. Thus CSR as a common goal might enhance engagement [32]. Further, this study found internal CSR to be the strongest predictor of employee engagement. This is supported by [98] who reported that the way employees are treated is the ultimate test of a company's CSR. According to [99], employees' perceptions of the way their organization conducts business in accordance with morality and ethics beyond basic legal requirements, positively stimulates them, leading to positive relationship between ethical citizenship and work engagement. In contrast, [100] indicated that employees that perceive their organizations engaging in illegal behaviour and break the law will experience negative feelings of anxiety, suspicion, and insecurity resulting in the disengagement of those employees from their work.

In addition, organizations that are good citizens allow for employees to care for the well-being of each other, people in their communities, and the planet as a whole. Employees do not need to wait until they get home to be caring individuals, instead they 
can be more than just a profit-making machine and actually act as their true selves while also making money for the company [20]. External CSR was also found to be a predictor of employee engagement but to a lesser extent. Evidence suggests that externally focused corporate citizenship has a positive influence on employee engagement [101] [102] which is consistent with this study.

$\mathrm{H}_{03}$ : There is no statistically significant relationship (at the level $\alpha=0.05$ ) between employee engagement and organizational performance.

Employee engagement has become a top priority for businesses around the world. Business leaders recognize that having a highly engaged workforce leads to increased innovation, productivity, and bottom-line performance while reducing costs of hiring and retaining talented employees in a highly competitive talent market [14]. The literature indicates that employee engagement is closely related with organizational performance outcomes (see [103]-[105]). This study asserts this conclusion where it was found that employee engagement has a positive significant relationship with organizational performance. Companies with engaged employees have higher employee retention, productivity, profitability, growth, and customer satisfaction. Whereas companies with disengaged employees suffer from waste of effort and bleed talent, have less committed employees, face increased absenteeism, have less customer focus, less productivity, and reduced operating margins and net profits [56]. This may be attributed to three general behaviours demonstrated by engaged employees which include; say-the employee advocates for the organization to co-workers, and refers potential employees and customers, stay-the employee has an intense desire to be a member of the organization despite the opportunities to work elsewhere, strive-the employee exerts extra time, effort, and initiative to contribute to the success of the business [106]. Furthermore, engaged employees approach their tasks with a sense of self-investment, energy, and passion that translate into higher levels of performance [54]. As such by being focused, energetic, and fully engrossed in their jobs, engaged employees become highly motivated to direct their focused energy towards organizational goals [107].

Another possible reason for the association between employee engagement and organizational performance is the dimensions that makeup employee engagement. The first dimension is vigor which relates to high levels of positive energy and mental resilience while working, and the willingness to invest time and efforts in job tasks. The second dimension is dedication which relates to the state mind in which employees perceive their work as significant and meaningful. Finally absorption which relates to the cognitive aspects where employees experience their jobs as engrossing and something on which they are fully concentrated and difficult for a person to detach themselves from it [108]. Other researchers such as [109] contradicted the findings of this study as they reported low to moderate relationship between employee engagement and organizational outcomes like customer satisfaction, profit, productivity, turnover, and safety [96].

$\mathrm{H}_{04}$ : Employee engagement does not mediate the relationship between CSR and organizational performance. 
The results of this study showed that employee engagement fully mediates the relationship between CSR and organizational performance in a significant way. This result is supports the conclusion of [18] who suggested that CSR perceptions shape employees' subsequent attitudes and behaviours towards their organizations. They further suggested that CSR presents an important opportunity to influence employee engagement and in turn positive business outcomes that result from having an engaged workforce. Employees who perceive their organization as socially responsible would be more committed to the organization and outperform those employees who perceive the organization as irresponsible. This is likely to improve organizational performance because employees see a socially responsible organization as fair and reciprocate this fairness through dedication, loyalty, and increased productivity [18].

Organizations that provide positive psychological climate, good working conditions, job resources, and organizational support inspire their employees to give their best and go the extra mile to enhance the effective functioning of the organization. In addition, employees perform better when they experience positive practices at work such as being treated with respect, having opportunities to develop their careers, adequate reward and recognition for high performance etc. all of which relate to having internal CSR in the organization. Therefore, creating a positive work environment is of vital importance for employees to increase their work engagement and consequently help their organizations flourish [108] [110]. This is due to the fact that engaged employees are also more likely to view the organization as a healthy environment and therefore more likely to support the organization.

To sum, the motivation of this study was to determine the relationship between corporate social responsibility, employee engagement, and organizational performance. A theoretical model was proposed and empirical testing was completed using a sample of 350employees working at three different mobile telecommunication companies in Jordan. The findings increase our understanding of the importance of CSR, and its association with organizational performance through the presence of employee engagement. However, there are some limitations of the study.

The first limitation is the dependence on a single sector to apply the study on. Although mobile telecommunication companies are one of the most known companies for their corporate social responsibility, the results are confined to this sector alone and thus cannot be generalized to other sectors. Therefore future researchers should look into applying this study on different sectors to increase the generalizability of the results. Another limitation is that the proposed conceptual model which is based on the cross-sectional data from the three mobile telecommunication companies in Jordan. Longitudinal investigations can be undertaken to improve the reliability of the data. In addition, it might be possible that examining the main constructs in this study over a longer period would yield more insights into the associations between the research variables on organizational performance. Furthermore, the scales used to measure the various concepts of this study may present themselves as a limitation. Other researchers may choose different scales to determine whether similar or comparable results would 
be obtained. Also, the data and results reported in this study were based on a single country, Jordan, and in turn are applicable specifically to the Jordanian context. Thus, this raises inquiries regarding the generalizability to other cultures and different contexts. Therefore, further research is needed with regards to several countries since this would help to advance understanding of the CSR phenomenon and the conditions and outcomes of achieving it from different nationwide origins in different contexts. Moreover, the use of the [82] mediation model and [84] test may present a limitation in this study since they are regarded as simple and old fashioned ways for testing for mediation. More complex and modern ways for testing for mediation can be employed to make the results more reliable and current. Indeed, although this study investigated several hypotheses and offered empirical support for the acceptance and refusal of some of these hypotheses; more generalizations on the application of the theoretical premises that developed in building the research model will be needed. This is to say, a more generalized research model that compensate the current research limitations by adding further impacting variables to the model and obtaining a more representative sample from different sectors is needed.

\section{References}

[1] Masa'deh, R., Obeidat, O. and Tarhini, A. (2016) A Jordanian Empirical Study of the Associations among Transformational Leadership, Transactional Leadership, Knowledge Sharing, Job Performance, and Firm Performance: A Structural Equation Modelling Approach. Journal of Management Development, 35, 681-705.

http://dx.doi.org/10.1108/JMD-09-2015-0134

[2] Ramezan, M., Sanjaghi, M.E. and Baly, H.R.K. (2013) Organizational Change Capacity and Organizational Performance. Journal of Knowledge-Based Innovation in China, 5, 188-212. http://dx.doi.org/10.1108/JKIC-07-2013-0012

[3] Hernaus, T., Bach, M. and Vuksic, V. (2012) Influence of Strategic Approach to BPM on Financial and Non-Financial Performance. Baltic Journal of Management, 7, 376-396.

[4] Gross, R. (2014) Corporate Social Responsibility and Employee Engagement: Making the Connection. White Paper.

http://www.charities.org/sites/default/files/corporate_responsibility_white_paper\%20copy. pdf

[5] Aras, G. and Crowther, D. (2008) Governance and Sustainability: An Investigation into the Relationship between Corporate Governance and Corporate Sustainability. Management Decision, 46, 433-448. http://dx.doi.org/10.1108/00251740810863870

[6] Misani, N. (2010) The Convergence of Corporate Social Responsibility Practices. Management Research Review, 33, 734-748. http://dx.doi.org/10.1108/01409171011055816

[7] Turcsanyi, J. and Sisaye, S. (2013) Corporate Social Responsibility and Its Link to Financial Performance. World Journal of Science, Technology and Sustainable Development, 10, 418. http://dx.doi.org/10.1108/20425941311313065

[8] Ali, I., Rehman, K.U., Ali, S.I., Yousaf, J. and Zia, M. (2010) Corporate Social Responsibility Influences, Employee Commitment and Organizational Performance. African Journal of Business Management, 4, 2796-2801.

[9] Alfermann, A.L. (2011) The Effects of Corporate Social Responsibility on Employee Engagement in a Global Setting. Unpublished PhD Dissertation, Benedictine University, Lisle. 
[10] JK Group (2014) Building Employee Engagement through Corporate Giving Programs. http://www.jk-group.com/Content/whitepapers/JKGroup-ExecutiveBrief-Jan2014.pdf

[11] Meister, J. (2012) Corporate Social Responsibility: A Lever for Employee Attraction \& Engagement.

http://www.forbes.com/sites/jeannemeister/2012/06/07/corporate-social-responsibility-a-le ver-for-employee-attraction-engagement/

[12] Nanderam, D.R. (2010) Corporate Social Responsibility and Employee Engagement: An Exploratory Case Study. Unpublished PhD Dissertation, Capella University, Minneapolis.

[13] Shahin, A., Naftchali, J.S. and Pool, J.K. (2014) Developing a Model for the Influence of Perceived Organizational Climate on Organizational Citizenship Behaviour and Organizational Performance Based on Balanced Score Card. International Journal of Productivity and Performance Management, 63, 290-307.

http://dx.doi.org/10.1108/IJPPM-03-2013-0044

[14] Harvard Business Review (2013) The Impact of Employee Engagement on Performance. https://hbr.org/resources/pdfs/comm/achievers/hbr_achievers_report_sep13.pdf

[15] Strandberg, C. (2009) The Role of Human Resource Management in Corporate Social Responsibility.

https://www.ic.gc.ca/eic/site/csr-rse.nsf/vwapj/CSR_and_HR_Management1.pdf/\$file/CSR_ and_HR_Management1.pdf

[16] Shannak, R., Obeidat, B. and Masadeh, R. (2012) Culture and the Implementation Process of Strategic Decisions in Jordan. Journal of Management Research, 4, 257-281.

http://dx.doi.org/10.5296/jmr.v4i4.2160

[17] Alshbiel, S.O. and AL Awawdeh, W.M. (2011) Internal Social Responsibility and Its Impact on Job Commitment: Empirical Study on Jordanian Cement Manufacturing Co. International Journal of Business and Management, 6, 94-102. http://dx.doi.org/10.5539/ijbm.v6n12p94

[18] Aguilera, R.V., Rupp, D.E., Williams, C.A. and Ganapathi, J. (2007) Putting the S Back in Corporate Social Responsibility: A Multi-Level Theory of Social Change in Organizations. Academy of Management Review, 32, 836-863. http://dx.doi.org/10.5465/AMR.2007.25275678

[19] Campbell, J.L. (2006) Institutional Analysis and the Paradox of Corporate Social Responsibility. American Behavioural Scientist, 49, 925-938. http://dx.doi.org/10.1177/0002764205285172

[20] Glavas, A. and Piderit, S.K. (2009) How Does Doing Good Matter? Effects of Corporate Citizenship on Employees. Journal of Corporate Citizenship, 2009, 51-70. http://dx.doi.org/10.9774/GLEAF.4700.2009.wi.00007

[21] Hansen, D., Dunford, B., Boss, A., Boss, R. and Angermeier, I. (2011) Corporate Social Responsibility and the Benefits of Employee Trust: A Cross-Disciplinary Perspective. Journal of Business Ethics, 102, 29-45. http://dx.doi.org/10.1007/s10551-011-0903-0

[22] Kim, W., Kim, J.A. and Kim, T. (2012) The Relationship between Work Engagement and Performance: A Review of Empirical Literature and a Proposed Research Agenda. Human Resource Development Review, 12, 248-276. http://dx.doi.org/10.1177/1534484312461635

[23] Rettab, B., Brik, A.B. and Mellahi, K. (2009) A Study of Management Perceptions of Impact of Corporate Social Responsibility on Organizational Performance in Emerging Economic: A Case of Dubai. Journal of Business Ethics, 89, 317-390. http://dx.doi.org/10.1007/s10551-008-0005-9

[24] Albdour, A.A. and Altarawneh, I.I. (2012) Corporate Social Responsibility and Employee 
Engagement in Jordan. International Journal of Business and Management, 7, 89-105. http://dx.doi.org/10.5539/ijbm.v7n16p89

[25] Moura-Leite, R.C. and Padgett, R.C. (2011) Historical Background of Corporate Social Responsibility. Social Responsibility Journal, 7, 528-539.

http://dx.doi.org/10.1108/1747111111117511

[26] Rigoberto, J. and Daza, P. (2009) A Valuation Model for Corporate Social Responsibility. Social Responsibility Journal, 5, 284-299. http://dx.doi.org/10.1108/17471110910977230

[27] D'Amato, A. and Roome, N. (2009) Toward an Integrated Model of Leadership for Corporate Responsibility and Sustainable Development: A Process Model of Corporate Responsibility beyond Management Innovation. Corporate Governance: The International Journal of Business in Society, 9, 421-434. http://dx.doi.org/10.1108/14720700910984972

[28] McWilliams, A., Siegel, D.S. and Wright, P.M. (2006) Corporate Social Responsibility: Strategic Implications. Journal of Management Studies, 43, 1-18. http://dx.doi.org/10.1111/j.1467-6486.2006.00580.x

[29] Spitzeck, H.T. (2009) The Development of Governance Structures for Corporate Responsibility. Corporate Governance: The international journal of business in society, 9, 495-505.

[30] Al Azmi, N., Al-Lozi, M., Al-Zu’bi, Z., Dahiyat, S. and Masa'deh, R. (2012) Patients Attitudes toward Service Quality and Its Impact on Their Satisfaction in Physical Therapy in KSA Hospitals. European Journal of Social Sciences, 34, 300-314.

[31] Obeidat, B., Sweis, R., Zyod, D., Masa'deh, R. and Alshurideh, M. (2012) The Effect of Perceived Service Quality on Customer Loyalty in Internet Service Providers in Jordan. Journal of Management Research, 4, 133-151. http://dx.doi.org/10.5296/jmr.v4i4.2130

[32] Ferreira, P. and De Oliveira, E.R. (2014) Does Corporate Social Responsibility Impact on Employee Engagement? Journal of Workplace Learning, 26, 232-247. http://dx.doi.org/10.1108/JWL-09-2013-0070

[33] Grbac, B. and Loncaric, D. (2009) Ethics, Social Responsibility and Business Performance in a Transition Economy. EuroMed Journal of Business, 4, 143-158. http://dx.doi.org/10.1108/14502190910976501

[34] KPMG (2008) KPMG International Survey of Corporate Responsibility Reporting 2008.

[35] Bénabou, R. and Tirole, J. (2010) Individual and Corporate Social Responsibility. Economica, 77, 1-19. http://dx.doi.org/10.1111/j.1468-0335.2009.00843.x

[36] Cegarra-Navarro, J.G. and Martínez-Martínez, A. (2009) Linking Corporate Social Responsibility with Admiration through Organizational Outcomes. Social Responsibility Journal, 5, 499-511. http://dx.doi.org/10.1108/17471110910995357

[37] Buciuniene, I. and Kazlauskaitè, R. (2012) The Linkage between HRM, CSR and Performance Outcomes. Baltic Journal of Management, 7, 5-24. http://dx.doi.org/10.1108/17465261211195856

[38] Schwartz, M.S. and Carroll, A.B. (2003) Corporate Social Responsibility: A Three-Domain Approach. Business Ethics Quarterly, 13, 503-530. http://dx.doi.org/10.5840/beq200313435

[39] Cochius, T. (2006) Corporate Social Responsibility in Dutch SMEs. Unpublished Thesis, Maastricht University, Maastricht.

[40] Ligeti, G. and Oravecz, A. (2009) CSR Communication of Corporate Enterprise in Hungary. Journal of Business Ethics, 84, 137-149. http://dx.doi.org/10.1007/s10551-008-9678-3

[41] Smith, A.D. (2007) Making the Case for the Competitive Advantage of Corporate Social Responsibility. Business Strategy Series, 8, 186-195. http://dx.doi.org/10.1108/17515630710684187 
[42] Brammer, S., Millington, A. and Rayton, B. (2005) The Contribution of Social Responsibility to Organizational Commitment. Working Paper Series 2005.20, School of Management, University of Bath, Bath.

[43] Pietersz, G. (2011) Corporate Social Responsibility Is More than Just Donating Money. KPMG International, Curacao.

[44] Skudiene, V. and Auruskeviciene, V. (2012) The Contribution of Corporate Social Responsibility to Internal Employee Motivation. Baltic Journal of Management, 7, 49-67. http://dx.doi.org/10.1108/17465261211197421

[45] Longo, M., Mura, M. and Bonoli, A. (2005) Corporate Social Responsibility and Corporate Performance: The Case of Italian SMEs. Corporate Governance: The international journal of business in society, 5, 28-42. http://dx.doi.org/10.1108/14720700510616578

[46] European Commission (2001) Promoting a European Framework for Corporate Social Responsibility. Green Paper, European Commission, Brussels.

[47] Graafland, J. and van de Van, B. (2006) Strategic and Moral Motivation for Corporate Social Responsibility. Journal of Corporate Citizenship, 2006, 111-123. http://dx.doi.org/10.9774/GLEAF.4700.2006.su.00012

[48] Papasolomou-Doukakis, I., Krambia-Kapardis, M. and Katsioloudes, M. (2005) Corporate Social Responsibility: The Way Forwards? Maybe Not!: A preliminary study in Cyprus. European Business Review, 17, 263-279. http://dx.doi.org/10.1108/09555340510596661

[49] Khan, W.A. (1990) Psychological Conditions of Personal Engagement and Disengagement of Work. Academy of Management Journal, 33, 692-724. http://dx.doi.org/10.2307/256287

[50] Robinson, D., Perryman, S. and Hayday, S. (2004) The Drivers of Employee Engagement Report 408. Institute for Employment Studies, UK.

[51] MacLeod, D. and Clarke, N. (2009) Engaging for Success: Enhancing Performance through Employee Engagement. Office of Public Sector Information, London.

[52] Hewitt (2010) CSR as a Driver of Employee Engagement. http://www.cucentral.ca/cusr/Resources/Hewitt\%202010\%20Best $\% 20$ Employers\%20in\%20 Can-ada\%20Study\%20\%20Corporate\%20Social\%20Responsibility\%20Research\%20Finding s\%20-\%20final.pdf

[53] Shuck, B. and Wollard, K. (2010) Employee Engagement and HRD: A Seminal Review of the Foundations. Human Resource Development Review, 9, 89-110. http://dx.doi.org/10.1177/1534484309353560

[54] Ariani, D.W. (2013) The Relationship between Employee Engagement, Organizational Citizenship Behavior, and Counterproductive Work Behavior. International Journal of Business Administration, 4, 46-56.

[55] Vratskikh, I., Masadeh, R., Al-Lozi, M. and Maqableh, M. (2016) The Impact of Emotional Intelligence on Job Performance via the Mediating Role of Job Satisfaction. International Journal of Business and Management, 11, 69-91. http://dx.doi.org/10.5539/ijbm.v11n2p69

[56] Markos, S. and Sridevi, M.S. (2010) Employee Engagement: The Key to Improving Performance. International Journal of Business and Management, 5, 89-96.

[57] Sahoo, C.K. and Sahu, G. (2009) Effective Employee Engagement: The Mantra of Achieving Organizational Excellence. Management and Labour Studies, 34, 73-84. http://dx.doi.org/10.1177/0258042X0903400105

[58] AL-Syaidh, N., Masa'deh, R., Al-Lozi, M. and AlHarrasi, J. (2015) Transformational Leadership and Its Role on the Effectiveness of Employees' Behavior: A Theoretical Study. Journal of Business \& Management (COES\&RJ-JBM), 4, 14-35. 
[59] Schaufeli, W.B., Schaufeli, A.B. and Salanova, M. (2006) The Measurement of Work Engagement with a Short Questionnaire. Educational and Psychological Measurement, 66, 701-716. http://dx.doi.org/10.1177/0013164405282471

[60] Masa'deh, R. (2016) The Role of Emotional Intelligence in Enhancing Organizational Effectiveness: The Case of Information Technology Managers in Jordan. International Journal of Communications, Network and System Sciences, 9, 234-249. http://dx.doi.org/10.4236/ijcns.2016.96022

[61] Yunis, M., Jung, J. and Chen, S. (2013) TQM, Strategy, and Performance: A Firm-Level Analysis. International Journal of Quality \& Reliability Management, 30, 690-714. http://dx.doi.org/10.1108/02656711311325638

[62] Abu Jarad, I., Yusof, N. and Shafiei, M.W.M. (2010) The Organizational Performance of Housing Developers in Peninsular Malaysia. International Journal of Housing Markets and Analysis, 3, 146-162. http://dx.doi.org/10.1108/17538271011049768

[63] Almajali, D., Maqableh, M. and Masa'deh, R. (2015) Assessing the Digital Divide Status of the Jordanian Telecentre. International Journal of Communications, Network and System Sciences, 8, 428-439. http://dx.doi.org/10.4236/ijcns.2015.811039

[64] Cho, T. (2011) Knowledge Management Capabilities and Organizational Performance: An Investigation into the Effects of Knowledge Infrastructure and Processes on Organizational Performance. Unpublished PhD Thesis, University of Illinois.

[65] Gavrea, C., Ilies, L. and Stegerean, R. (2011) Determinants of Organizational Performance: The Case of Romania. Management \& Marketing Challenges for the Knowledge Society, 6, 285-300.

[66] Griffin, M. (2003) Organizational Performance Model.

[67] Carton, R.B. (2004) Measuring Organizational Performance: An Exploratory Study. Unpublished PhD Thesis, University of Georgia, Athens.

[68] Antony, J.P. and Bhattacharyya, S. (2010) Measuring Organizational Performance and Organizational Excellence of SMEs-Part 2: An Empirical Study on SMEs in India. Measuring Business Excellence, 14, 42-52. http://dx.doi.org/10.1108/13683041011074209

[69] Al-Dmour, R., Obeidat, B., Masa'deh, R. and Almajali, D. (2015) The Practice of HRIS Applications in Business Organizations in Jordan: An Empirical Study. Proceedings of the 4th Scientific \& Research Conference on New Trends in Business, Management and Social Sciences (COES\&RJ-TK15/1), Istanbul, 19-20 September, 53-74.

[70] Skrinjar, R., Bosilj-Vuksic, V. and Indihar-Stemberger, M. (2008) The Impact of Business Process Orientation on Financial and Non-Financial Performance. Business Process Management Journal, 14, 738-754. http://dx.doi.org/10.1108/14637150810903084

[71] Fernandes, K., Raja, V. and Whalley, A. (2006) Lessons from Implementing the Balanced Scorecard in a Small and Medium Size Manufacturing Organization. Technovation, 26, 623-634. http://dx.doi.org/10.1016/j.technovation.2005.03.006

[72] Obeidat, B., El-Rimawi, S., Masa'deh, R., Maqableh, M. and Al-Jarrah, I. (2013) Evaluating the Profitability of the Islamic Banks in Jordan. European Journal of Economics, Finance and Administrative Sciences, 56, 27-36.

[73] Tseng, S.M. (2010) The Correlation between Organizational Culture and Knowledge Conversion on Corporate Performance. Journal of Knowledge Management, 14, 269-284. http://dx.doi.org/10.1108/13673271011032409

[74] Alkalha, Z., Al-Zu'bi, Z., Al-Dmour, H., Alshurideh, M. and Masa'deh, R. (2012) Investigating the Effects of Human Resource Policies on Organizational Performance: An Empirical Study on Commercial Banks Operating in Jordan. European Journal of Economics, Fi- 
nance and Administrative Sciences, 51, 44-64.

[75] Kuo, T.H. (2011) How to Improve Organizational Performance through Learning and Knowledge? International Journal of Manpower, 32, 581-603. http://dx.doi.org/10.1108/01437721111158215

[76] Arab Advisors Group (2014) Cellular Competition Intensity Index. http://arabadvisors.com/reports/item/14881

[77] Maqableh, M., Masa'deh, R., Shannak, R. and Nahar, K. (2015) Perceived Trust and Payment Methods: An Empirical Study of MarkaVIP Company. International Journal of Communications, Network and System Sciences, 8, 409-427. http://dx.doi.org/10.4236/ijcns.2015.811038

[78] Kateb, M., Swies, G., Obeidat, B., Masa'deh, R. and Maqableh M. (2015) An Investigation on the Critical Factors of Information System Implementation in Jordanian Information Technology Companies. European Journal of Business and Management, 7, 11-28.

[79] Sekaran, U. and Bougie, R. (2013) Research Methods for Business: A Skill-Building Approach. 6th Edition, Wiley, New York.

[80] Bagozzi, R. and Yi, Y. (1988) On the Evaluation of Structural Evaluation Models. Journal of the Academy of Marketing Science, 16, 74-94. http://dx.doi.org/10.1007/BF02723327

[81] Kumar, S.A., Mani, B.T., Mahalingam, S. and Vanjikovan, M. (2010) Influence of Service Quality on Attitudinal Loyalty in Private Retail Banking: An Empirical Study. The IUP Journal of Management Research, 9, 21-38.

[82] Baron, R.M. and Kenny, D. (1986) The Moderator-Mediator Variable Distinction in Social Psychological Research: Conceptual, Strategic, and Statistical Considerations. Journal of Personality and Social Psychology, 51, 1173-1182. http://dx.doi.org/10.1037/0022-3514.51.6.1173

[83] Preacher, K.J. and Hayes, A.F. (2004) SPSS and SAS Procedures for Estimating Indirect Effects in Simple Mediation Models. Behavior Research Methods, Instruments, and Computers, 36, 717-731. http://dx.doi.org/10.3758/BF03206553

[84] Sobel, M.E. (1982) Asymptotic Confidence Intervals for Indirect Effects in Structural Equation Models. In: Leinhart, S., Ed., Sociological Methodology, Jossey-Bass, San Francisco, 290-312.

[85] Dabbas, M. and Al Rawashdeh, S.T. (2012) The Effect of Corporate Social Responsibility on the Profitability of the Industrial Companies in Jordan. Canadian Social Science, 8, 32-37.

[86] Jin, K.G. and Drozdenko, R.G. (2010) Relationships among Perceived Organizational Core Values, Corporate Social Responsibility, Ethics, and Organizational Performance Outcomes: An Empirical Study of Information Technology Professionals. Journal of Business Ethics, 92, 341-359. http://dx.doi.org/10.1007/s10551-009-0158-1

[87] Luo, X. and Bhattacharya, C.B. (2006) Corporate Social Responsibility, Customer Satisfaction, and Market Value. Journal of Marketing, 70, 1-18.

http://dx.doi.org/10.1509/jmkg.70.4.1

[88] Orlitzky, M., Schmidt, F.L. and Rynes, S.L. (2003) Corporate Social and Financial Performance: A Meta-Analysis. Organization Studies, 24, 403-441. http://dx.doi.org/10.1177/0170840603024003910

[89] Yu, Y. and Choi, Y. (2014) Corporate Social Responsibility and Firm Performance through the Mediating Effect of Organizational Trust in Chinese Firms. Chinese Management Studies, 8, 577-592. http://dx.doi.org/10.1108/CMS-10-2013-0196

[90] Erhemjamts, O., Li, Q. and Venkateswaran, A. (2013) Corporate Social Responsibility and 
its Impact on Firms' Investment Policy, Organizational Structure, and Performance. Journal of Business Ethics, 118, 395-412. http://dx.doi.org/10.1007/s10551-012-1594-x

[91] Aras, G., Aybars, A. and Kutlu, O. (2010) Managing Corporate Performance Investigating the Relationship between Corporate Social Responsibility and Financial Performance in Emerging Markets. International Journal of Productivity and Performance Management, 59, 229-254. http://dx.doi.org/10.1108/17410401011023573

[92] Freedman, M. and Jaggi, B. (1982) Pollution Disclosures, Pollution Performance and Economic Performance. Omega, 10, 167-176. http://dx.doi.org/10.1016/0305-0483(82)90051-2

[93] Surroca J., Tribò, J.A. and Waddock, S. (2010) Corporate Responsibility and Financial Performance: The Role of Intangible Resources. Strategic Management Journal, 31, 463-490. http://dx.doi.org/10.1002/smj.820

[94] Pearce, G.L. and Ensley, M.D. (2004) A Reciprocal and Longitudinal Investigation of the Innovation Process: The Central Role of Shared Vision in Product and Process Innovation Teams. Journal of Organizational Behavior, 25, 259-278. http://dx.doi.org/10.1002/job.235

[95] Fenwick, T. and Bierema, L. (2008) Corporate Social Responsibility: Issues for HRD Engagement. International Journal of Training and Development, 12, 24-35. http://dx.doi.org/10.1111/j.1468-2419.2007.00293.x

[96] Harter, J.K., Schmidt, F.L. and Hayes, T.L. (2002) Business-Unit-Level Relationship between Employee Satisfaction, Employee Engagement, and Business Outcomes: A MetaAnalysis. Journal of Applied Psychology, 87, 268-279.

http://dx.doi.org/10.1037/0021-9010.87.2.268

[97] Tajfel, H. and Turner, J.C. (1985) The Social Identity Theory of Intergroup Behaviour. In: Worchel, S. and Austin, W.G., Eds., Psychology of Intergroup Relations, 2nd Edition, Nelson Hall, Chicago, 7-24.

[98] Mirvis, P. (2012) Employee Engagement and CSR: Transactional, Relational, and Developmental Approaches. California Management Review, 54, 93-117. http://dx.doi.org/10.1525/cmr.2012.54.4.93

[99] Lin, C.P. (2009) Modeling Corporate Citizenship, Organizational Trust, and Work Engagement Based on Attachment Theory. Journal of Business Ethics, 94, 517-531. http://dx.doi.org/10.1007/s10551-009-0279-6

[100] Chughtai, A.A. and Buckley, F. (2007) The Relationship between Work Engagement and Foci of Trust: A Conceptual Analysis. Proceedings of the 13 th Asia Pacific Management Conference, Melbourne, 73-85.

[101] AlHrassi, J., Masa'deh, R., Al-Lozi, M. and Irtaimeh, H. (2016) The Impact of Management Innovation and Technological Innovation on Organizational Effectiveness: An Empirical Study from Managerial Staff Perspective in Sultan Qaboos University. Journal of Social Sciences (COES\&RJ-JSS), 5, 309-339.

[102] Rego, A., Leal, S., Cunha, M., Faria, J. and Pinho, C. (2010) How the Perceptions of Five Dimensions of Corporate Citizenship and Their Inter-Inconsistencies Predict Affective Commitment. Journal of Business Ethics, 94, 107-127. http://dx.doi.org/10.1007/s10551-009-0252-4

[103] Bagnato, G. and Paolino (2009) HRM Practices, Work Engagement and Firm Performance: An Empirical Study. Ticonzero, 95, 4-5.

[104] Harter, J.K., Schmidt, F.L., Agarwal, S. and Plowman, S. K. (2013) The Relationship between Engagement at Work and Organizational Outcomes. Gallup New Directions Consulting.

[105] Robertson, I.T., Birch, A.J. and Cooper, C.L. (2012) Job and Work Attitudes, Engagement 
and Employee Performance: Where Does Psychological Well-Being Fit in? Leadership \& Organization Development Journal, 33, 224-232.

http://dx.doi.org/10.1108/01437731211216443

[106] Baumruk, R. and Gorman, B. (2006) Why Managers Are Crucial to Increasing Engagement. Melcrum Publishing.

[107] Macey, W.H. and Schneider, B. (2008) The Meaning of Employee Engagement. Industrial and Organizational Psychology, 1, 3-30. http://dx.doi.org/10.1111/j.1754-9434.2007.0002.x

[108] Kataria, A., Garg, P. and Rastogi, R. (2013) Employee Engagement and Organizational Effectiveness: The Role of Organizational Citizenship Behavior. International Journal of Business Insights \& Transformation, 6, 102-113.

[109] Halbesleben, J.R.B. and Wheeler, A.R. (2008) The Relative Roles of Engagement and Embeddedness in Predicting Job Performance and Intention to Leave. Work \& Stress, 22, 242 256. http://dx.doi.org/10.1080/02678370802383962

[110] Masa'deh, R., Gharaibeh, A., Tarhini, A. and Obeidat, O. (2015) Knowledge Sharing Capability: A Literature Review. Proceedings of the 4 th Scientific \& Research Conference on New Trends in Business, Management and Social Sciences (COES\&RJ-TK15/1), Istanbul, 19-20 September, 1-16.

Submit or recommend next manuscript to SCIRP and we will provide best service for you:

Accepting pre-submission inquiries through Email, Facebook, LinkedIn, Twitter, etc. A wide selection of journals (inclusive of 9 subjects, more than 200 journals)

Providing 24-hour high-quality service

User-friendly online submission system

Fair and swift peer-review system

Efficient typesetting and proofreading procedure

Display of the result of downloads and visits, as well as the number of cited articles Maximum dissemination of your research work

Submit your manuscript at: http://papersubmission.scirp.org/ 